\title{
The Effect of Industrial Work Practice, Vocational Guidance and Achievement Motivation on Work Readiness of Students Accounting Department in Smk Majenang
}

\author{
1 Urip*, 2 Tri Kuat \\ Email : ${ }^{1}$ uripsoebagdja@gmail.com*, 2 trikuat@mpv.uad.ac.id \\ * : coresponndensing author \\ 12 Universitas Ahmad Dahlan
}

Article history

Received Aug 30, 2021

Revised Nov 30, 2021

Accepted Nov 30, 2021

Keywords

internship

vocational guidance

achievement motivation

work readiness
This study aims (1) to know the positive effect of internship towards work readiness of vocational students; (2) to know the positive effect of vocational guidance on vocational students' work readiness; (3) to know the positive effect of achievement motivation on vocational students' work readiness; (4) know the positive and significant influence together between fieldwork practices, vocational guidance, achievement motivation for student work readiness.

The research method used is quantitative. The population in this study were all vocational students majoring in accounting in Majenang, the sampling technique used was random sampling with an error rate of $5 \%$. Data collection techniques using a questionnaire with a Likert scale and five alternative answers. The validity test uses the Pearson product moment formula, while the reliability test uses the Alpha formula. Data analysis methods are simple linear regression analysis and multiple regression analysis.

The results of the study stated that there was a positive influence of internship on vocational students' work readiness of 0.687 and it was found that internship could contribute to job readiness by $37.2 \%$, there was a positive influence on vocational guidance on vocational work readiness of 0.765 students and obtained that guidance vocational can contribute to student work readiness by $4.7 \%$, there is a positive influence of achievement motivation on vocational student work readiness by 1,053 and it is found that achievement motivation can contribute to student work readiness by $6 \%$, there is a positive influence jointly between internship, vocational guidance, achievement motivation to work readiness of vocational students by $47.9 \%$ means that together the contribution of all independent variables to the dependent variable is $47.9 \%$ the remaining $52.1 \%$ by variables and other factors outside this study that are not explained by pen elite

This is an open access article under the CC-BY-SA license.

\section{Introduction}

Clarke \& Winch in Retno (2010) stated that vocational education is an effort to develop social employment, maintain, accelerate and improve the quality of certain workforce in order to increase 
community productivity. Vocational High School as one of the institutions that prepares the workforce is required to be able to produce graduates as expected by the world of work (Supriadi, 2002).

The implementation PKL is part of the PSG which is an innovation of vocational education where students do internships in industries that are relevant to their expertise programs for a certain period of time (Nifah, 2015). The implementation of PKL requires SMK students to better understand the culture in the industry such as quality, productivity, efficiency, and good service and demands a change in the mindset, attitudes and behavior of street vendors that has never been done before.

Kurniawati (2015) stated that vocational guidance has a very important role in fostering student maturity to think about the future, so that students can make decisions about their career plans related to work readiness.

Achievement motivation is a physiological and psychological condition (need for achievement) contained in students that encourages them to carry out certain activities in order to achieve certain goals (highest possible achievement) (Djaali, 2012). Achievement motivation is the driving force to achieve the highest possible level of learning achievement for the sake of hope for oneself as an effort to achieve success and aim to succeed in competition with a measure of excellence.

Factors that can affect job readiness are: learning motivation, external practice experience, vocational guidance, parents' economic background, previous learning achievements, job information, and expectations of entering the world of work (Sulistyarini, 2012).

\section{Method}

The research method used is quantitative. Research that emphasizes the analysis on numerical data or numbers obtained by statistical methods in order to obtain the significance of the relationship between the variables studied ( Sugiyono, 2010 ) . Quantitative research methods can be interpreted as research methods based on sampling techniques are generally carried out randomly, data collection using research instruments, data analysis is quantitative/statistical with the purpose of a predetermined hypothesis.

\subsection{Data Source}

The population in this study was 70 students consisting of SMK students majoring in Accounting who had done industrial work practice at SMK KH Ahmad Dahlan Cimanggu, SMK Muhammadiyah Cimanggu, SMK Yos Sudarso Majenang. The sampling technique used was random sampling.

Taking the number of samples from a certain population developed by isaac and michael, for error rates of $1 \%, 5 \%$ and $10 \%$. Based on the table if it has a population of 70 with an error rate of $5 \%$, then the number of samples in this study is 58 students. The distribution is done equally for 
each school with the results of SMK KH Ahmad Dahlan Cimanggu 17 students, SMK Muhammadiyah Cimanggu 24 students and SMK Yos Sudarso Majenang 17 students.

\subsubsection{Data Analysis Technique}

Data analysis technique used regression analysis technique. The condition for using the regression test is to use the classical assumption test. The classical assumption test includes:

1. Normality test

2. Linearity Test.

3. Multicollinearity Test

4. Heteroscedasticity Test

\section{Result and Discussion}

\section{Result}

The development model used in this research is quantitative research.

\section{Classical Assumption Test}

\section{Normality test}

Table 1. Normality Test

One-Sample Kolmogorov-Smirnov Test

\begin{tabular}{|c|c|c|c|c|c|}
\hline & & PKL (X1) & $\begin{array}{l}\text { Vocational } \\
\text { Guidance } \\
\text { (X2) }\end{array}$ & $\begin{array}{c}\text { Achieveme } \\
n t \\
\text { Motivation } \\
\text { (X3) } \\
\end{array}$ & $\begin{array}{c}\text { Work } \\
\text { Readiness } \\
\text { (Y) }\end{array}$ \\
\hline \multicolumn{2}{|l|}{$\mathrm{N}$} & 58 & 58 & 58 & 58 \\
\hline \multirow[t]{2}{*}{ Normal Parameters ${ }^{a}$} & Mean & 62.93 & 38.91 & 42.31 & 71.34 \\
\hline & $\begin{array}{l}\text { Std. } \\
\text { Deviation }\end{array}$ & 6.078 & 3.664 & 4.272 & 7.373 \\
\hline \multirow{3}{*}{$\begin{array}{l}\text { Most Extreme } \\
\text { Differences }\end{array}$} & Absolute & .084 & .096 & .102 & .090 \\
\hline & Positive & .082 & .081 & .102 & .090 \\
\hline & Negative & -.084 & -.096 & -.082 & -.060 \\
\hline \multicolumn{2}{|l|}{ Kolmogorov-Smirnov Z } & .643 & .728 & .778 & .682 \\
\hline \multicolumn{2}{|c|}{ Asymp. Sig. (2-tailed) } & .802 & .664 & .581 & .740 \\
\hline
\end{tabular}

Asymp.Sig significant value (2-tailed) PKL (X 1 ) of 0.802>0.05, vocational guidance (X 2 ) 0 , $664>0.05$, achievement motivation (X 3 ) $0.581>0.05$ and work readiness (Y) $0.740>0.05$. Based on the basis of decision-making in the Kolmogorov-Smirnov test for normality over Ha accepted and Ho rejected by asymp value. Sig.(2-taild) of the four variables $>0.05$, it was concluded that the data were normally distributed. Assumptions or normality prerequisites in the regression model have been met. 


\section{Linearity Test}

1. The effect of Industrial Work Practice of vocational students

Table 2. Linearity Test of Industrial Work Practice on the readiness of the students' work

\begin{tabular}{|c|c|c|c|c|c|c|c|}
\hline \multicolumn{8}{|c|}{ ANOVA Table } \\
\hline & & & $\begin{array}{l}\text { Sum of } \\
\text { Squares }\end{array}$ & df & $\begin{array}{l}\text { Mean } \\
\text { Square }\end{array}$ & $\mathrm{F}$ & Sig. \\
\hline \multirow{5}{*}{$\begin{array}{l}\text { Work Readiness } \\
(\mathrm{Y}){ }^{*} \mathrm{PKL}(\mathrm{X} 1)\end{array}$} & \multirow{3}{*}{$\begin{array}{l}\text { Between } \\
\text { Groups }\end{array}$} & (Combined) & 1739.603 & 21 & 82.838 & 2.194 & .019 \\
\hline & & Linearity & 993.489 & 1 & 993.489 & $\begin{array}{r}26.30 \\
8\end{array}$ & .000 \\
\hline & & $\begin{array}{l}\text { Deviation from } \\
\text { Linearity }\end{array}$ & 746.115 & 20 & 37.306 & .988 & .497 \\
\hline & Within Groups & & 1359.500 & 36 & 37.764 & & \\
\hline & Total & & 3099.103 & 57 & & & \\
\hline
\end{tabular}

The significant value (Sig) of the data is above 0.497 . Ho is accepted if the value of Sig deviation from linearity $<0.05$, Ha is accepted if the value of Sig. deviation from linearity $>$ 0.05. The value of Sig $0.497>0.05$ concluded that Ho was rejected and Ha was accepted, means that there was a significant linear relationship between the PKL variable (X 1 ) and the work readiness variable (Y).

2. The Effect of Vocational Guidance on Students' Job Readiness

Table 3 Linearity test of vocational guidance to students working

\begin{tabular}{|c|c|c|c|c|c|c|c|}
\hline \multicolumn{8}{|c|}{ ANOVA Table } \\
\hline & & & $\begin{array}{c}\text { Sum of } \\
\text { Squares }\end{array}$ & df & $\begin{array}{l}\text { Mean } \\
\text { Square }\end{array}$ & $\mathrm{F}$ & Sig. \\
\hline \multirow{3}{*}{\multicolumn{2}{|c|}{$\begin{array}{l}\text { Work Readiness }(\mathrm{Y}) \text { Betu } \\
\text { * } \\
\text { Vocational } \\
\text { Guidance }(\mathrm{X} 2)\end{array}$}} & (Combined) & $\begin{array}{r}1042.08 \\
2\end{array}$ & 14 & 74.434 & 1.556 & $\begin{array}{r}.13 \\
2\end{array}$ \\
\hline & & Linearity & 283.688 & 1 & 283.688 & 5.930 & $\begin{array}{r}.01 \\
9\end{array}$ \\
\hline & & $\begin{array}{l}\text { Deviation from } \\
\text { Linearity }\end{array}$ & 758.394 & 13 & 58.338 & 1.219 & $\begin{array}{r}.29 \\
9\end{array}$ \\
\hline & Within Groups & & $\begin{array}{r}2057.02 \\
1\end{array}$ & 43 & 47.838 & & \\
\hline & Total & & $\begin{array}{r}3099.10 \\
3\end{array}$ & 57 & & & \\
\hline
\end{tabular}

The significant value (Sig) of the data is above 0.299. Ho is accepted if the value of Sig deviation from linearity $<0.05$, Ha is accepted if the value of Sig. deviation from linearity $>0.05$. Sig value of 0, $299>0.05$ was concluded that Ha accepted and Ha rejected means that there is a linear relationship between the variables significantly Guidance Motivation (X 2 ) with job readiness variable (Y).

3. The Influence of Achievement Motivation on Students' Work Readiness 
Tabel 4. Linearity test of Achievement motivation on students' work readiness

ANOVA Table

\begin{tabular}{|c|c|c|c|c|c|c|c|}
\hline & & & $\begin{array}{l}\text { Sum of } \\
\text { Squares }\end{array}$ & $\mathrm{df}$ & $\begin{array}{l}\text { Mean } \\
\text { Square }\end{array}$ & $\mathrm{F}$ & Sig. \\
\hline \multirow{5}{*}{$\begin{array}{l}\text { Work readiness } \\
(Y)^{*} \\
\text { Achievement } \\
\text { Motivation }(X 3)\end{array}$} & \multirow{3}{*}{$\begin{array}{l}\text { Between } \\
\text { Groups }\end{array}$} & (Combined) & 1465.067 & 16 & 91.567 & 2.298 & .016 \\
\hline & & Linearity & 1154.120 & 1 & $\begin{array}{r}1154.12 \\
0\end{array}$ & 28.958 & .000 \\
\hline & & $\begin{array}{l}\text { Deviation from } \\
\text { Linearity }\end{array}$ & 310.946 & 15 & 20.730 & .520 & .914 \\
\hline & Within Groups & & 1634.037 & 41 & 39.855 & & \\
\hline & Total & & 3099.103 & 57 & & & \\
\hline
\end{tabular}

The significant value (Sig) of the data is above 0.914 . Ho is accepted if the value of Sig deviation from linearity $<0.05$, Ha is accepted if the value of Sig. deviation from linearity $>0.05$. The value of Sig $0.914>0.05$ concluded that Ho was rejected and Ha was accepted, means that there was a significant linear relationship between the Achievement Motivation variable (X 3 ) and the work readiness variable (Y).

\section{Multicollinearity Test}

Tabel 5. Multicollinearity Test

\section{Coefficients $^{\mathrm{a}}$}

\begin{tabular}{|c|c|c|c|c|c|c|c|c|c|c|c|}
\hline & \multirow[t]{2}{*}{ Model } & \multicolumn{2}{|c|}{$\begin{array}{c}\text { Unstandardiz } \\
\text { ed } \\
\text { Coefficients }\end{array}$} & $\begin{array}{c}\text { Standardiz } \\
\text { ed } \\
\text { Coefficient } \\
\text { s }\end{array}$ & \multirow[t]{2}{*}{$\mathrm{t}$} & \multirow[t]{2}{*}{ Sig. } & \multicolumn{3}{|c|}{ Correlations } & \multicolumn{2}{|c|}{$\begin{array}{l}\text { Collinearity } \\
\text { Statistics }\end{array}$} \\
\hline & & B & $\begin{array}{l}\text { Std. } \\
\text { Error }\end{array}$ & Beta & & & $\begin{array}{l}\text { Zero- } \\
\text { order }\end{array}$ & Partial & Part & $\begin{array}{c}\text { Toleran } \\
\text { ce }\end{array}$ & VIF \\
\hline \multirow[t]{4}{*}{1} & (Constant) & $\begin{array}{r}25.89 \\
0\end{array}$ & 8.560 & & $\begin{array}{r}3.02 \\
5\end{array}$ & .004 & & & & & \\
\hline & PKL (X1) & .462 & .165 & .381 & $\begin{array}{r}2.79 \\
6\end{array}$ & .007 & .566 & .356 & .274 & .519 & $\begin{array}{r}1.92 \\
8\end{array}$ \\
\hline & $\begin{array}{l}\text { Vocational } \\
\text { Guidance } \\
\text { (X2) }\end{array}$ & .729 & .289 & .362 & $\begin{array}{r}2.52 \\
0\end{array}$ & .015 & .303 & .324 & .247 & .466 & $\begin{array}{r}2.14 \\
4\end{array}$ \\
\hline & $\begin{array}{l}\text { Achievement } \\
\text { Motivation } \\
\text { (X3) }\end{array}$ & 1.057 & .262 & .613 & $\begin{array}{r}4.03 \\
0\end{array}$ & .000 & .610 & .481 & .395 & .417 & $\begin{array}{r}2.39 \\
9\end{array}$ \\
\hline
\end{tabular}

Coefficients Table a show that value PKL (X 1 ) 0, 519 , Vocational Guidance (X 2 ) 0, 466 , Achievement Motivation (X 3 ) 0, 417 to have a value of tolerance $>0.10$, which means there is no correlation between variables independent. Thus it can be said that there is no multicollinearity. 


\section{Heteroscedasticity Test}

Tabel 6. Heteroscedasticity Test

\section{Correlations}

\begin{tabular}{|c|c|c|c|c|c|c|}
\hline & & & PKL & $\begin{array}{c}\text { Bimbinga } \\
n \\
\text { Vokasion } \\
\text { al }\end{array}$ & $\begin{array}{l}\text { Motivasi } \\
\text { Berpresta } \\
\text { si }\end{array}$ & $\begin{array}{c}\text { Unstandard } \\
\text { ized } \\
\text { Residual }\end{array}$ \\
\hline \multirow[t]{12}{*}{$\begin{array}{l}\text { Spearman } \\
\text { 's rho }\end{array}$} & PKL & $\begin{array}{l}\text { Correlation } \\
\text { Coefficient }\end{array}$ & 1.000 & $.611^{* *}$ & $.661^{* *}$ & .013 \\
\hline & & Sig. (2-tailed) & . & .000 & .000 & .926 \\
\hline & & $\mathrm{N}$ & 58 & 58 & 58 & 58 \\
\hline & Vocational Guidance & $\begin{array}{l}\text { Correlation } \\
\text { Coefficient }\end{array}$ & $.611^{* *}$ & 1.000 & $.738^{\star *}$ & -.018 \\
\hline & & Sig. (2-tailed) & .000 & . & .000 & .892 \\
\hline & & $\mathrm{N}$ & 58 & 58 & 58 & 58 \\
\hline & $\begin{array}{l}\text { Achievement } \\
\text { motivation }\end{array}$ & $\begin{array}{l}\text { Correlation } \\
\text { Coefficient }\end{array}$ & $.661^{* *}$ & $.738^{* *}$ & 1.000 & -.005 \\
\hline & & Sig. (2-tailed) & .000 & .000 & . & .969 \\
\hline & & $\mathrm{N}$ & 58 & 58 & 58 & 58 \\
\hline & $\begin{array}{l}\text { Unstandardized } \\
\text { Residual }\end{array}$ & $\begin{array}{l}\text { Correlation } \\
\text { Coefficient }\end{array}$ & .013 & -.018 & -.005 & 1.000 \\
\hline & & Sig. (2-tailed) & .926 & .892 & .969 & \\
\hline & & $\mathrm{N}$ & 58 & 58 & 58 & 58 \\
\hline
\end{tabular}

**. Correlation is significant at the 0.01 level (2tailed).

The results of the correlation calculation are known that the significance value or Sig. (2tailed) PKL variable is 0.926 , vocational guidance variable is 0.892 and achievement motivation variable is 0.969 . From the value of the three variables above, it shows $p>0.05$, so there is no heteroscedasticity.

\section{Hypothesis Test}

\section{Partial Significance Test (t Test)}

1. The Effect of PKL on Student Work Readiness

Table 7 Partial Test Results (t-test) PKL

\section{Coefficientsa}

\begin{tabular}{lrrrrrr}
\hline \multirow{2}{*}{ Model } & \multicolumn{2}{c}{ Unstandardized Coefficients } & \multicolumn{2}{c}{$\begin{array}{c}\text { Standardized } \\
\text { Coefficients }\end{array}$} & \multirow{2}{*}{ t } & \multirow{2}{*}{ Sig. } \\
\cline { 2 - 5 } & \multicolumn{1}{c}{$\mathrm{B}$} & \multicolumn{2}{c}{ Std. Error } & \multicolumn{1}{c}{ Beta } & & \\
\hline 1 & (Constant) & 28.119 & 8.448 & & 3.329 & .002 \\
PKL $(\mathrm{X} 1)$ & .687 & .134 & .566 & 5.140 & .000 \\
\hline
\end{tabular}

a. Dependent Variable: Work Readiness $(\mathrm{Y})$ 
The constant coefficient value is 28.119 with a t-count of 3.329 and a significant value of 0.002 . The slope coefficient of street vendors is 0.687 with a t count of 5.140 and a significant value of 0.000 ; while the significance slope of PKL is 0.000 which is smaller than alpha $(0.000<0.05)$; implies that street vendors have an effect on student work readiness.

2. The Effect of Vocational Guidance on Students' Work Readiness

Table 8. Partial Test Results (t-test) vocational guidance

\begin{tabular}{|c|c|c|c|c|c|c|}
\hline \multicolumn{7}{|c|}{ Coefficientsa } \\
\hline & \multirow{2}{*}{ Model } & \multicolumn{2}{|c|}{ Unstandardized Coefficients } & \multirow{2}{*}{$\begin{array}{c}\begin{array}{c}\text { Standardized } \\
\text { Coefficients }\end{array} \\
\text { Beta } \\
\end{array}$} & \multirow[t]{2}{*}{$\mathrm{t}$} & \multirow[t]{2}{*}{ Sig. } \\
\hline & & $\mathrm{B}$ & Std. Error & & & \\
\hline \multirow[t]{2}{*}{1} & (Constant) & 41.389 & 9.945 & & 4.162 & .000 \\
\hline & $\begin{array}{l}\text { Bimbingan Vokasional } \\
\text { (X2) }\end{array}$ & .765 & .253 & .375 & 3.025 & .004 \\
\hline
\end{tabular}

a. Dependent Variable: Work Readiness $(\mathrm{Y})$

The constant coefficient value is 41,389 with t count of 4.162 and significant of 0.000 . The slope coefficient of vocational guidance is 0.765 with a t count of 3.025 and a significant value of 0.004; while the slope of the significance of vocational guidance is 0.004 smaller than alpha 0.004 $<0.05$ ); implies that vocational guidance has a significant effect on student work readiness.

3. The Influence of Achievement Motivation on Students' Work

Table 9 Partial Test Results (t-test) achievement motivation

\section{Coefficients $^{\mathrm{a}}$}

\begin{tabular}{|c|c|c|c|c|c|c|}
\hline & \multirow{2}{*}{ Model } & \multicolumn{2}{|c|}{ Unstandardized Coefficients } & \multirow{2}{*}{$\begin{array}{c}\begin{array}{c}\text { Standardized } \\
\text { Coefficients }\end{array} \\
\text { Beta }\end{array}$} & \multirow[t]{2}{*}{$\mathrm{t}$} & \multirow{2}{*}{ Sig. } \\
\hline & & $\mathrm{B}$ & Std. Error & & & \\
\hline & (Constant) & 26.782 & 7.769 & & 3.447 & .001 \\
\hline & Motivasi Berprestasi (X3) & 1.053 & .183 & .610 & 5.764 & .000 \\
\hline
\end{tabular}

a. Dependent Variable: Kesiapan Kerja (Y)

The constant coefficient value is 26,782 with t count of 3,447 and significant of 0.001 . The coefficient of achievement motivation slope is 1.053 with a t count of 5.764 and a significant value of 0.000 ; while the significance slope of achievement motivation is 0.000 which is smaller than alpha $(0.000<0.05)$; implies that achievement motivation has a significant effect on student work readiness.

\section{Simultaneous Significant Test (Test F)}

The Influence of PKL, Vocational Guidance, Achievement Motivation on Students' Work Readiness. Table 10. Simultaneous Test Results (Test F ) of street vendors, vocational guidance, achievement motivation and work readiness. 


\begin{tabular}{|c|c|c|c|c|c|c|}
\hline \multicolumn{7}{|c|}{ ANOVA $^{\mathrm{b}}$} \\
\hline & Model & Sum of Squares & df & Mean Square & $\mathrm{F}$ & Sig. \\
\hline \multirow[t]{3}{*}{1} & Regression & 1487.576 & 3 & 495.859 & 16.616 & $.000^{\mathrm{a}}$ \\
\hline & Residual & 1611.527 & 54 & 29.843 & & \\
\hline & Total & 3099.103 & 57 & & & \\
\hline
\end{tabular}

a. Predictors: (Constant), Motivasi Berprestasi (X3), PKL (X1), Bimbingan Vokasional (X2)

b. Dependent Variable: Work Readiness $(Y)$

The test results simultaneously ( test F ) above were obtained from data processing SPSS 16.0 above can be viewed with the level of 0.05 is significantly below 0,000 then the hypothesis is accepted. Based on the decision making simultaneous test (F test) in the regression analysis can be concluded that PKL variable (X 1 ) Vocational Guidance (X 2 ) and Moivasi Achievement (X 3 ) when tested together with a significant effect on the readiness of the students' work.

\section{Coefficient of Simultaneous Determination (R2)}

The Influence of PKL, Vocational Guidance, Achievement Motivation on Students' Work Readiness

Tabel 11. Test The coefficient of determination (R 2 ) PKL, vocational guidance, achievement motivation, work readiness.

\section{Model Summary}

\begin{tabular}{|c|c|c|c|c|}
\hline Model & $\mathrm{R}$ & R Square & Adjusted R Square & $\begin{array}{l}\text { Std. Error of the } \\
\text { Estimate }\end{array}$ \\
\hline 1 & $.610^{\mathrm{a}}$ & .372 & .361 & 5.893 \\
\hline 2 & $.647^{b}$ & .419 & .398 & 5.722 \\
\hline 3 & $.692^{\mathrm{c}}$ & .479 & .450 & 5.468 \\
\hline
\end{tabular}

a. Predictors: (Constant), Motivasi Berprestasi (X3)

b. Predictors: (Constant), Motivasi Berprestasi (X3), PKL (X1)

c. Predictors: (Constant), Motivasi Berprestasi (X3), PKL (X1), Bimbingan Vokasional (X2)

The magnitude of the coefficient of determination ( $R 2$ ) is 0.479 . The effective contribution or contribution jointly between the variables of street vendors, vocational guidance, achievement motivation on student work readiness is 0.479 or $47.9 \%$ consisting of the 1 st stage $37.2 \%$ to the 2nd stage $41.9 \%$ and the 3rd stage $47,9 \%$. If we look at the change in contribution, there is an addition from $\mathrm{X} 2$ by $4.7 \%$ and an addition from $\mathrm{X} 3$ by $6 \%$. This means that $47.9 \%$ of students' work readiness is influenced by street vendors, vocational guidance and achievement motivation. While the remaining $52.1 \%$ is influenced by other variables not examined.

\section{Conclusion}

Based on the results of data analysis and research discussion, it can be concluded that: 
1. There is a positive effect of field work practices (PKL) on the work readiness of students majoring in accounting at SMK Majenang.

2. There is a positive influence of vocational guidance on the work readiness of students majoring in accounting at SMK Majenang.

3. There is a positive influence of achievement motivation on the work readiness of students majoring in accounting at SMK Majenang.

4. Field work practices, vocational guidance and achievement motivation together have a positive and significant effect on students' work readiness.

\section{Acknowledgement}

I would like to thank the supervisor and the leadership of SMK KH Ahmad Dahlan Cimanggu, SMK Muhammadiyah Cimanggu, SMK Yos Sudarso Majenang who have allowed this research, teachers and students who have helped the research process so that it runs smoothly.

\section{References}

Djaali. (2012). Psikologi Pendidikan. Jakarta : PT Bumi Aksara

Kurniawati, A., \& Arief, S. (2016). Pengaruh efikasi diri, minat kerja, dan bimbingan karir terhadap kesiapan kerja siswa SMK program kehlian akuntansi. Economic Education Analysis Journal, 5(1).

Nifah, A. (2015). Pengaruh pengalaman praktik kerja industri (prakerin), efikasi diri, dan kompetensi akuntansi terhadap kesiapan kerja siswa kelas XII program keahlian akuntansi di SMK PGRI 2 Kota Salatiga tahun ajaran 2014/2015. Universitas Negeri Semarang. Semarang.

Retno, S. (2010). Pengsruh praktik industri dalam menunjang kesiapan memasuki dunia kerja siswa kelas XII kompetensi keahlian administrasi perkantoran SMK N 1 Bantul. Universitas Negeri Yogyakarta. Yogyakarta.

Sugiyono, P. (2010). 2010. Metode penelitian kuantitatif, kualitatif, dan R\&D. Bandung: CV Alfabeta.

Supriadi, Arismunandar, Soenaryo, dkk. (2002). Sejarah pendidikan teknik dan kejuruan di Indonesia, membangun manusia produktif. Jakarta: Departemen Pendidikan Nasional, Direktorat Jendral Pendidikan Dasar dan Menengah, Direktorat Pendidikan Menengah Kejuruan.

Sulistyarini, E. P. D. (2012). Pengaruh motivasi memasuki dunia kerja dan pengalaman praktik kerja industri terhadap kesiapan kerja peserta didik kelas XII program keahlian akuntansi SMK 